\title{
Beetroot as a Potential Functional Food for Cancer Chemoprevention, a Narrative Review
}

\author{
Mei Lan Tan, ${ }^{1,2}$ Shahrul Bariyah Sahul Hamid ${ }^{2}$ \\ ${ }^{1}$ School of Pharmaceutical Sciences, Universiti Sains Malaysia, Minden, ${ }^{2}$ Advanced Medical and Dental Institute, Universiti \\ Sains Malaysia, Kepala Batas, Pulau Pinang, Malaysia
}

Patients with cancer are prone to several debilitating side effects including fatigue, insomnia, depression and cognitive disturbances. Beetroot (Beta vulgaris L.) as a health promoting functional food may be potentially beneficial in cancer. As a source of polyphenols, flavonoids, dietary nitrates and other useful nutrients, beetroot supplementation may provide a holistic means to prevent cancer and manage undesired effects associated with chemotherapy. The main aim of this narrative review is to discuss beetroot's nutrient composition, current studies on its potential utility in chemoprevention and cancer-related fatigue or treatment-related side effects such as cardiotoxicity. This review aims to provide the current status of knowledge and to identify the related research gaps in this area. The flavonoids and polyphenolic components present in abundance in beetroot support its significant antioxidant and anti-inflammatory capacities. Most in vitro and in vivo studies have shown promising results; however, the molecular mechanisms underlying chemopreventive and chemoprotective effects of beetroot have not been completely elucidated. Although recent clinical trials have shown that beetroot supplementation improves human performance, translational studies on beetroot and its functional benefits in managing fatigue or other symptoms in patients with cancer are still lacking.

Key Words Beetroot, Betacyanin, Betaxanthin, Betanin, Cancer

\section{INTRODUCTION}

Patients with cancer are prone to several debilitating effects due to chemotherapy or the disease itself. The behavioural disturbances experienced by patients with cancer include fatigue, insomnia, depression, and cognitive disturbances. These symptoms are very common and may persist for months or years even after completion of treatment and may affect patient's quality of life. Functional foods have long been linked to improve human performance and health, and hence are considered beneficial as part of the cancer patients' diet.

Beetroot (Beta vulgaris L.) is one of high-nutrient vegetables used for salads and juices, and a valuable source of natural pigments. It belongs to the botanical order Amaranthaceae-Chenopodiaceae, which is cultivated commercially. Beetroot, also known as table or garden beet, is usually grown for its roots. It has a characteristic earthy mushy aroma and flavour, mainly due to the presence of geosmin, a volatile bicyclic alcoholic compound [1]. Beetroot is known for its antioxidant activities and widely used as a remedy for a variety of ailments including cardiovascular-related conditions, anemia, sexual weakness and bladder stones [2]. Some recent clinical studies have also indicated the usefulness of beetroot in managing blood pressure and cardiovascular health [3-6]. Beetroot has also gained popularity as a supplement to boost energy and improve performance in athletes [7-10].

Interestingly, in the Traditional Persian Medicine practices, beetroot is one of the foods used in the prevention and managing of metastatic progression of cancer [11]. It is also widely used in other medicinal systems including the Arab, traditional Chinese and Ayurvedic medicine. Beetroot, juiced or blended, is a popular functional food among breast, prostate and colorectal cancer patients as reported in Trinidad. A study at two clinical sites on the island revealed that beetroot is being consumed by patients for the purpose of treatment, health improvement and amelioration of side effects associated with chemotherapy treatment [12]. Similarly, beetroot is also the most frequently used alternative dietetic measure among patients with cancer in Germany [13] and among a majority of gastrointestinal cancer patients in Serbia [14].

Received February 3, 2021, Revised February 27, 2021, Accepted March 5, 2021

Correspondence to Mei Lan Tan, E-mail: tanml@usm.my, https://orcid.org/0000-0001-6565-699X

Check for updates

(i) (\$) This is an Open Access article distributed under the terms of the Creative Commons Attribution Non-Commercial License, which permits unrestricted noncommercial use, distribution, and reproduction in any medium, provided the original work is properly cited.

Copyright (C) 2021 Korean Society of Cancer Prevention 
Red beetroot is highly popular and widely used for cancer patients in some parts of the world. Although there is paucity of data indicating its direct role in cancer treatment and chemoprevention its antioxidant, anti-inflammatory and other supplementary effects are potentially beneficial for patients with cancer at certain stages of disease including during chemotherapy and post-chemotherapy. This narrative review aims highlight to provide the valuable phytochemical components present in red beetroot, the current knowledge on its health benefits as a possible chemopreventive functional food and to identify related research gaps in this area of research.

\section{DATA ANALYSIS}

To summarize the current literature on beetroot and cancer, three databases such as Pubmed, Sciencedirect and Springerlink were screened. The search terms used included beet, beetroot, sugar beet, beta vulgaris, cancer, antioxidant, anti-inflammatory, cardioprotective, anti-tumor, chemoprevention, fatigue, performance and clinical trials using Boolean operator "AND" in various combinations. Articles were first screened by year (2000 to 2021), followed by title, language and abstract. Only relevant articles were selected, and additional articles were sourced by examining the bibliographic list. Flowchart illustrating the brief search strategy is shown in Figure 1.

\section{Phytochemical and nutritional composition of beetroot}

Phytochemicals present in beetroot are found to be beneficial for the human health. Betalains, pigments derived from betalamic acid, are an important group of bioactive phytochemicals in beetroot. Structurally, betalains are compounds with

\section{Flowchart illustrating search strategy}

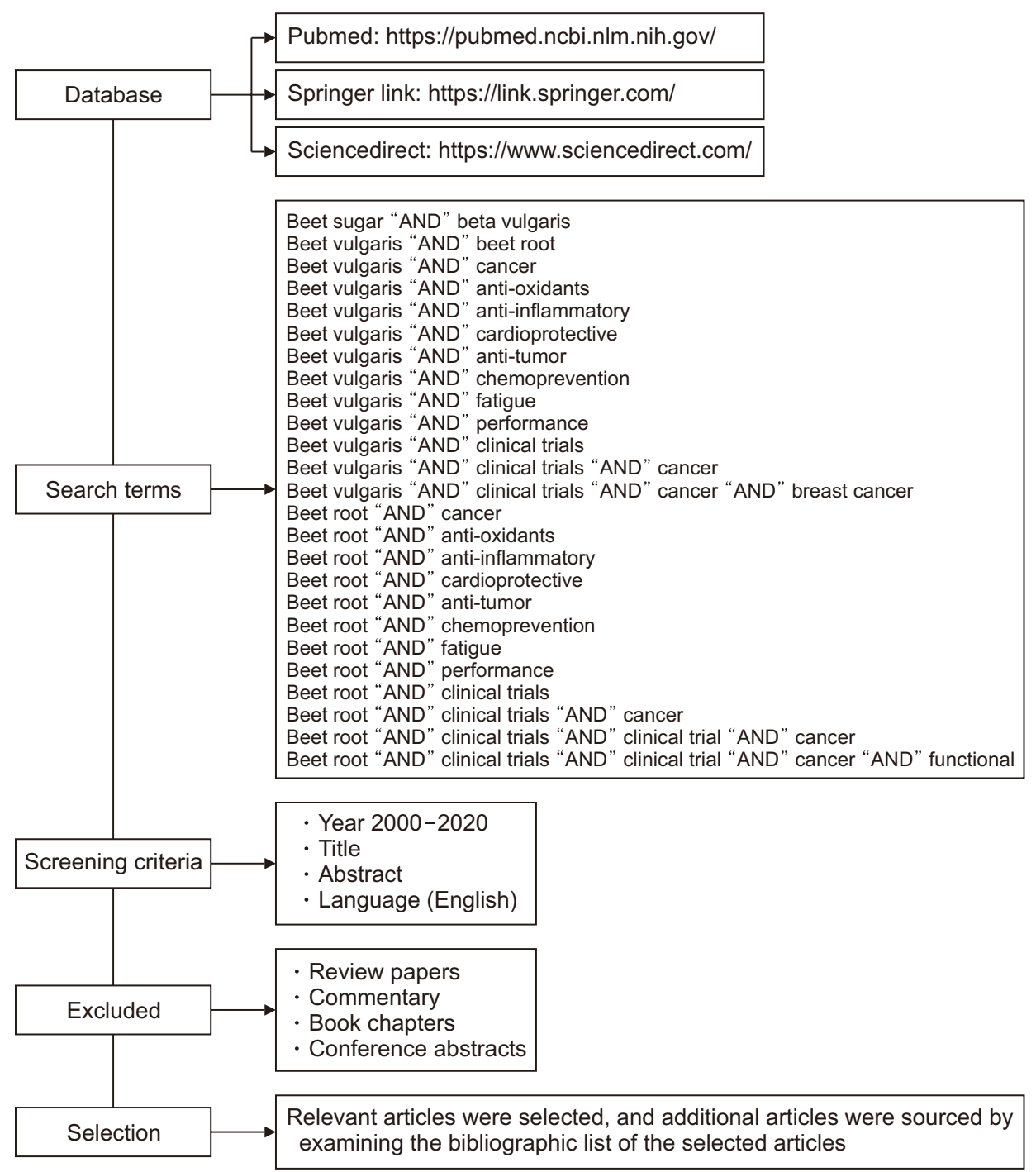

Figure 1. Flowchart illustrating the search strategy for studies related to beetroot and cancer. 
positive nitrogen in a polyene system and this cyclic amine reactive group has been considered an important contributor to their reducing properties [15]. According to a recent study, red beetroot has the richest source of betalains among all tested plants such as prickly pear (Opuntia ficus-indica) and white beetroot varieties [16]. Betalains are synthesised from tyrosine into the yellow-orange betaxanthins and red-violet betacyanins [17]. Betalamic acid (Fig. 2A) is the common chromophore for all betalain compounds. The pigment classification as either betaxanthin (Fig. 2B) or betacyanin is dependent on the way in which betalamic acid is added as a residue (Fig. 2C). Betaxanthins (Fig. 2B), are betalamic acid conjugated with an amine or amino acid. Meanwhile, the betacyanins (Fig. 2C) are the end products of spontaneous Schiff base condensation between the conjugated betalamic acid moiety and the closed structure of cyclo-DOPA (cyclo-3,4-dihydroxy-phenylalanine) [17]. This reaction changes the absorption from $480 \mathrm{~nm}$ (betaxanthins, yellow) to 540 $\mathrm{nm}$ (betacyanins, violet). The colour is due to the presence of double bonds resonating in the structures. Red beetroot contains a large amount of betacyanins but lower levels of betanidin and betaxanthins [18]. More than $80 \%$ of total red beetroot pigments are made of betacyanins, mainly betanin (betanidin 5-O- $\beta$-glucoside) (Fig. 2D) and its isomer, isobetanin (Fig. 2E). The concentration of betanin in red beet was reported to be 300 to $600 \mathrm{mg} / \mathrm{kg}$ [19]. Other betacyanins reported include prebetanin, neobetanin, amaranthin, lampranthin I and lampranthin II [20-23].
Other classes of phytochemicals found in beetroot include phenolics and flavonoids. Some betalains are also phenolic compounds, namely, isobetanin, prebetanin and neobetanin, vulgaxanthin I, vulgaxanthin II and indicaxanthin [24]. Other phenolic compounds isolated from beetroot include 5,5,6,6-tetrahydroxy-3,3-biindolyl, N-trans-feruloyltyramine, $\mathrm{N}$-trans-feruloylhomovanillylamine, and phenolic acids such as 4-hydroxybenzoic acid, chlorogenic acid, caffeic acid, catechin hydrate and epicatechin [25-27]. On the other hand, flavonoids are, in general, secondary metabolites with a polyphenolic structure. They are typical biologically active compounds with health-promoting properties and are important components used for various applications. The flavonoids present in beetroot include betagarin, betavulgarin, cochliophilin A and dihydroisorhamnetin [28]. Other flavonoid compounds isolated are 3,5-dihydroxy-6,7-methylenedioxyflavanone, 2,5-dihydroxy-6,7-methylenedioxyisoflavone, quercetin, rutin and kaempferol $[20,24,28-31]$. The major contributor to the earthy flavor in red beet is geosmin (trans-1,10-dimethyltrans-9-decanol) [32,33]. Another unique feature of beetroot is its high concentration of volatile compounds such as pyridine and 4-methylpyridine. Additional components present include furfural, isopentanol, ethanol, dimethyl sulfide and isovaleraldehyde [32]. A summary of the phytochemical and nutritional components is shown in Table 1.

The basic nutritional composition of beetroot includes sugars, dietary fibre, fatty acids, minerals and vitamins (Table 1) $[27,34]$. Among sugars present, sucrose is the main com-
A<smiles>O=CC=C1C=C(C(=O)O)N[C@H](C(=O)O)C1</smiles>

B<smiles>[R][N+]([R])=CC=C1C=C(C(=O)O)N[C@H](C(=O)O)C1</smiles><smiles>[R3]Oc1cc2c(cc1O[R3])[N+](=CC=C1C=C(C(=O)O)N[C@H](C(=O)O)C1)[C@H](C(=O)O)C2</smiles>

D<smiles>O=C(O)C1=CC(=CC=[N+]2c3cc(O)c(OC4O[C@@H](O)[C@H](O)[C@@H](O)[C@H]4O)cc3C[C@H]2C(=O)O)C[C@@H](C(=O)O)N1</smiles>

E<smiles>O=C(O)C1=C/C(=C/C=[N+]2c3cc(O)c(OC4O[C@@H](O)[C@@H](O)[C@H](O)[C@H]4O)cc3C[C@H]2C(=O)O)C[C@@H](C(=O)O)N1</smiles>

Figure 2. Chemical structures of: (A) Betalamic acid; (B) Betaxanthin, where R1 is an amine or amino acid and R2 is normally hydrogen; (C) Betacyanins (when R3 and R4 are hydrogen, the structure corresponds to betanidin); (D) Betanin; (E) Isobetanin. 
Table 1. Phytochemical and nutritional composition of beetroot

\begin{tabular}{|c|c|c|c|c|}
\hline \multirow{2}{*}{$\frac{\text { No }}{1}$} & \multicolumn{2}{|c|}{ Class } & Compound (synonym) & \multirow[t]{2}{*}{ References } \\
\hline & Betalains & Betaxanthin & & \\
\hline & & Betacyanin & Betanin (betanidin 5-O-beta-glucoside) & {$[17,27]$} \\
\hline & & & Isobetanin (isobetanidin 5-O-beta-glucoside) & \\
\hline & & & Prebetanin (betanidin 5-O-(6'-sulfate)-beta-glucoside) & \\
\hline & & & Neobetanin (neobetanidin 5-O-beta-glucoside) & \\
\hline & & & Amaranthin (betanidin 5-O-sophorobiuronic acid) & [20-23] \\
\hline & & & Lampranthin I & \\
\hline & & & Lampranthin II & \\
\hline \multirow[t]{16}{*}{2} & Phenolics & Betalains & Vulgaxanthin I & {$[20,67]$} \\
\hline & & & Vulgaxanthin II & \\
\hline & & & Indicaxanthin & \\
\hline & & & Betanin (betanidin 5-O-beta-glucoside) & \\
\hline & & & Isobetanin (isobetanidin 5-O-beta-glucoside) & \\
\hline & & & Prebetanin (betanidin 5-O-(6'-sulfate)-beta-glucoside) & \\
\hline & & & Neobetanin (neobetanidin 5-O-beta-glucoside) & \\
\hline & & Non-betalains & 5,5,6,6-tetrahydroxy-3,3-biindolyl & {$[25-27,34]$} \\
\hline & & & 5,6-dihydroxyindolecarboxylic acid & \\
\hline & & & $\mathrm{N}$-trans-feruloyltyramine & \\
\hline & & & $\mathrm{N}$-trans-feruloylhomovanillylamine & \\
\hline & & & 4-hydroxybenzoic acid & \\
\hline & & & Chlorogenic acid & \\
\hline & & & Caffeic acid & \\
\hline & & & Catechin hydrate & \\
\hline & & & Epicatechin & \\
\hline \multirow[t]{9}{*}{3} & Flavonoids & & Betagarin (5,2-dimethoxy-6,7-methylenedioxyflavanone) & {$[20,24,26,28-31,34]$} \\
\hline & & & $\begin{array}{l}\text { Betavulgarin (2'-hydroxy-5-methoxy-6,7- } \\
\text { methylenedioxyisoflavone) }\end{array}$ & \\
\hline & & & Cochliophilin A (5-hydroxy-6,7-methylenedioxyflavone) & \\
\hline & & & $\begin{array}{l}\text { Dihydroisorhamnetin (3,4',5,7-tetrahydroxy-3'- } \\
\text { methoxyflavanone) }\end{array}$ & \\
\hline & & & 3,5-dihydroxy-6,7-methylenedioxyisoflavanone & \\
\hline & & & 2,5-dihydroxy-6,7-methylenedioxyisoflavone & \\
\hline & & & Quercetin $\left(3,5,7,3^{\prime}, 4^{\prime}\right.$-pentahydroxyflavone) & \\
\hline & & & Rutin (3,3',4',5,7-pentahydroxyflavone-3-rutinoside) & \\
\hline & & & Kaempferol (3,4',5,7-tetrahydroxyflavone) & \\
\hline \multirow[t]{8}{*}{4} & Volatiles & & 4-methylpyridine & {$[32,33]$} \\
\hline & & & Pyridine & \\
\hline & & & Dimethylsulfide & \\
\hline & & & Isovaleraldehyde & \\
\hline & & & Ethanol & \\
\hline & & & Isopentanol & \\
\hline & & & Furfural (2-Furaldehyde) & \\
\hline & & & Geosmin (trans I, IO-dimethyl-trans-9-decalol) & \\
\hline \multirow[t]{13}{*}{5} & Nutritional & Mineral & Calcium & {$[34,35,39,42]$} \\
\hline & & & Magnesium & \\
\hline & & & Potassium & \\
\hline & & & Sodium & \\
\hline & & Vitamin & Vitamin A & \\
\hline & & & Vitamin C & \\
\hline & & Carbohydrate & Sucrose & \\
\hline & & Fat & Fatty acids & \\
\hline & & Amino acid & Essential amino acids (EAA) & \\
\hline & & & Non-essential amino acids (NEAA) - Glutamic acid & \\
\hline & & & Gamma-aminobutyric acid (GABA) & \\
\hline & & Others & Dietary nitrate $\left(\mathrm{NO}_{3}^{-}\right)$ & \\
\hline & & & Dietary fiber & \\
\hline
\end{tabular}


ponent. Fatty acids are present in combination of saturated, monounsaturated and polyunsaturated acids which occur in minimal amounts. Minerals such as sodium, potassium, calcium and magnesium are present in relatively high concentrations while aluminium, barium, boron, copper, iron, manganese and zinc are found at lower levels. Beetroot are also rich in both vitamins A and C [27]. Moreover, beetroot contains a substantial amount of both non-essential and essential amino acids. Examples are methionine, threonine, lysine, leucine, isoleucine, tryptophan, phenylalanine, valine, tyrosine, cysteine, alanine, histidine, arginine, serine, proline, glycine and aspartic acid [27]. Interestingly, a large amount of glutamine is also present in beets [35]. Glutamine is a non-essential amino acid and is a precursor in nucleotide, glucose and protein synthesis [36]. Its metabolism produces large quantities of glutamate, a component required for glutathione synthesis. Glutathione is important for the maintenance of the cellular redox state $[37,38]$. In addition, $\gamma$-aminobutyric acid (GABA) and $\beta$-alanine were also isolated from the red beetroot $[35,39]$. Interestingly, GABA is known to be potentially useful as a component of functional food. As an important inhibitory neurotransmitter in the nervous systems, GABA has antioxidant, anti-anxiety, anti-hypertensive properties [40,41].

Dietary nitrate found in green leafy and root vegetables such as beetroot is an important source of nitric oxide (NO) formed via the nitrate-nitrite-NO pathway [42]. Ingested inorganic $\mathrm{NO}_{3}^{-}$is metabolized in vivo to bioactive nitrite $\left(\mathrm{NO}_{2}^{-}\right)$ and $\mathrm{NO}_{2}^{-}$exerts its effects by conversion to functional nitrogen oxides, including NO [43]. NO is an important biologically active and signalling molecule involved in a multiple physiologic process, especially regulation of blood pressure and blood flow. It is a potent dilator, reduces systemic blood pressure and inhibits atherogenesis by reducing inflammatory cell recruitment and platelet aggregation [44]. NO-mediated signalling is crucial for protecting the heart against cellular injury or death. It also regulates mitochondrial respiration by inhibiting cytochrome $c$ oxidase [45]. Dietary nitrate is an important component of the "Dietary Approaches to Stop Hypertension (DASH)" diet to lower blood pressure and the Mediterranean diet to lower cardiovascular and cancer risk [46]. Nitrate and nitrite are known to reduce blood pressure, protect tissues against ischemic injury, reduce oxidative stress, improves mitochondrial function and enhances exercise performance.

\section{Properties of beetroot that are potentially chemopreventive}

\section{Antioxidant and anti-inflammatory activities}

Red beetroot has been ranked among the ten most potent antioxidant vegetables [47]. Betacyanins are known to be a class of compounds with radical scavenging and antioxidant activities $[18,48]$. On the other hand, betanin, consisting of a phenolic and a cyclic amine group, is shown to be a very good electron donor, acting as antioxidants [18]. Hence, its consumption may increases the protection against free radicals. Several earlier studies have also indicated that beetroot is an essential source of natural antioxidants [25,49-53]. Apparently, the antioxidant effects of beetroot is not limited to its tubers, but also evident in its leaves [54].

The antioxidant and anti-inflammatory capacity of beetroot has been evaluated in both in vitro and in vivo experiments. Beetroot ethanol extract (lyophilized) has shown substantial antioxidant, electron-donating ability and radical scavenging activities and was found to inhibit the nitric oxide production in lipopolysaccharide-treated mouse macrophage RAW 264.7 cells [55]. Antioxidant activity, evaluated using the cell-free system and three standard spectrophotometric tests, have shown that red beetroot extracts displayed the strongest antioxidant potential as compared with other vegetable extracts [16]. However, in the same study, there were no significant cytotoxic nor any protective effects against oxidative DNA damage in HT29 (human colon adenocarcinoma) cells challenged with reactive oxygen species (ROS) when 10\% (v/v) water extracts of red beetroot was tested [16]. Similarly, the water extracts were not found to induce the activity of phase II detoxification enzymes significantly. This is in contrary to earlier published studies. Esatbeyoglu and co-workers reported that betanin significantly reduced $\mathrm{H}_{2} \mathrm{O}_{2}$-induced DNA damage in HT29 cells [56]. Betanin at a low concentration (15 $\mu \mathrm{M})$ functioned as a free radical scavenger and as an inducer of endogenous cellular enzymatic antioxidant defence mechanisms [56]. However, the exact amount of betanin contained in the $10 \%(\mathrm{v} / \mathrm{v})$ water extract used in the earlier study was unclear and hence, difficult to compare with results of studies that used betanin alone.

In another study, the antioxidant capacity of betanin was also found to be prominent as it significantly diminished the intracellular ROS level elevated by phorbol myristate acetate (PMA) stimulation ( $\sim 3$ fold) and significantly enhanced caspase-3 activity in stimulated neutrophils [57]. Betanin also decreased the content of DNA in the Comet tails in the PMA-stimulated neutrophils [57]. Similar observation was found in another work using Caco-2 intestinal cells. Betanin was found to reduce DNA damage caused by $\mathrm{H}_{2} \mathrm{O}_{2}$ and significantly enhanced caspase- 3 activity in both neutrophils and Caco-2 cells [58]. Based on these findings, betanin is likely to be responsible for the effect of beetroot products on oxidative DNA damage and apoptosis in neutrophils. Since cytokines and other inflammatory mediators produced by the white blood cells are direct contributors to cancer initiation, promotion and metastasis, functional food which mitigates chronic inflammation is thought to be an important cancer prevention strategy.

Beetroot juice containing $79.3 \mathrm{mg} / 100 \mathrm{~mL}$ of betaxanthines and $159.6 \mathrm{mg} / 100 \mathrm{~mL}$ of betacyanins was found to be protective against $\mathrm{N}$-nitrosodiethylamine (NDEA)-induced oxidative stress and liver injury in male rats. NDEA is a food-born carcinogen and is present in smoked or salted meat [59]. 
The metabolic activation of NDEA by the hepatic microsomal cytochrome $\mathrm{P} 450$ system produces ethyl diazonium ion as a reactive intermediate which elicits DNA alkylation and subsequently promotes carcinogenesis. In this study, rats treated with beetroot juice prior to NDEA administration exhibited a significant reduction of DNA damage in blood leukocytes. Beetroot juice also restored the activity of some of the antioxidant enzymes in the liver and prevented xenobiotic-induced oxidative stress [59]. In addition, beetroot juice was found to reduce the levels of liver injury biomrkers including ALT, SDH, GGT and bilirubin and reduced DNA damage triggered by NDEA treatment [60]. The protective effect of beetroot juice against oxidative damages and the metabolic alterations induced by beetroot feeding may likely safeguard against liver damage [60]. Furthermore, the ethanol extract of beetroot was found to exert similar protective effects on hepatotoxicity by altering various indicators of liver damage induced by lipopolysaccharide or alcohol in experimental rats [55].

The anti-inflammatory effects of betalains and beetroot extract appear to be mediated by interfering with the NF- $\mathrm{NB}$ signalling cascade [2]. The transcription factor NF- $\mathrm{kB}$ promotes immunity directly by activating gene targets that up-regulates the inflammatory molecules such as chemokines and cytokines that stimulate the phagocytic cells [61]. In an animal model study to investigate the protective effect of beetroot extract on gentamicin-induced nephrotoxicity, up-regulation of nuclear expression of NF- $\kappa \mathrm{B}$ (p65), production of TNF- $\alpha$ and interleukin-16 (IL-6), myeloperoxidase activity, and the nitric oxide level were significantly down regulated upon beetroot supplementation [2]. Beetroot extract treatment also significantly reduced the expression of cleaved caspase-3 and Bax protein and up-regulated the anti-apoptotic Bcl-2 protein in the kidney cells. It ameliorated the extent of histologic renal injury and reduced inflammatory infiltration in the tubules [2].

Betalains were also reported to supress COX-2 expression, a pro-inflammatory enzyme responsible for prostaglandin biosynthesis [62-64]. The COX-2 inhibitory effects of betanin were found to be comparable to or greater than compounds such as lycopene, chlorophyll, bixin, $\beta$-carotene and cyanidin-3-O-glucoside. Its activities were also comparable to anti-inflammatory drugs such as celecoxib and ibuprofen [64]. Betanin-rich beetroot supplements, in sufficient doses, were capable of exhibiting anti-inflammatory effects in a way similar to synthetic drugs [65]. The anti-inflammatory effects of betanin were also demonstrated in the neutrophils from patients with bowel disease neutrophils. Betanin treatment for 24 hours in neutrophils isolated from blood of patients with Crohn's disease and ulcerative colitis showed an increased DNA damage in these cells, hence demonstrating a reduced neutrophil activity in inflammatory conditions [58].

\section{Anti-proliferative and other chemopreventive properties}

The anti-proliferative and chemopreventive activities of beet- root were demonstrated in both in vitro as well as in vivo (animal) studies. Betanin is also a major betacyanin component isolated from Opuntia ficus-indica. Several in vitro studies have indicated that betanin possesses cytotoxic and growth inhibitory activities against different cancer cell lines. For example, the proliferation of human chronic myeloid leukemia cell line (K562 cells) treated with betanin was reduced in a concentration- and time dependent manner with an $\mathrm{IC}_{50}$ value of $40 \mu \mathrm{M}$. Betanin-treated $\mathrm{K} 562$ cells appeared to undergo intrinsic apoptosis mediated by the mitochondrial release of cytochrome $c$ into the cytosol [66]. Betanin exerted its pro-apoptotic activities through activation of procaspase-3 cleavage and caspase- 3 activity followed by the loss of mitochondrial transmembrane potential [58]. This indicates that betanin elicits the release of ROS and triggers apoptotic cell death, further supporting its cancer preventive activity.

In addition, both betanin and betaine extracted from beetroots have demonstrated anti-proliferative effects against hepatocellular cells [67]. On the other hand, betacyanins tested in combination with vitexin-2-O-xyloside, produced a synergistic effect in inhibiting the proliferation of human urinary bladder cancer cells (T24) but not on normal human skin keratocytes. When used concurrently, both compounds increased the pro-apoptotic BAX protein levels and down regulated expression of BIRC5 (survivin) and CTNNB1 ( $\beta$-catenin) which are prosurvival components [68]. In yet another study, doxorubicin and red beetroot extract exerted synergistic cytotoxicity against human pancreatic, prostate and breast cancer cell lines [69]. Since there is similarity in the configuration and chemical structure of both betanin and doxorubicin, a possible mechanisms may include DNA intercalation [69].

Furthermore, Nowacki and co-workers [70] found that betanin-enriched beetroot extract induced apoptosis in breast cancer cells. Betanin/isobetanin-enriched concentrate produced from red beetroots inhibited proliferation of cancer cells and induced their death but has limited effects towards normal cells. The concentrate appeared to inhibit aggregated cancer cell proliferation (3D cell culture) through inhibition of the cell cycle progression, by decreasing the $\mathrm{G} 1$ cell number, promoting the increase of $S$ phase and down regulating cyclin A2 and cyclin B1 levels in the breast cancer cells [70]. Further, expression of FAS, TRAILR4, Bad and p53 (apoptotic-related proteins) was significantly induced and the mitochondrial membrane potential was clearly MCF-7 cells treated with betanin-enriched red beetroot. Suggesting that both intrinsic and extrinsic pathways were involved [70]. Although lysosomal vacuole formation was observed in the extract-treated MCF-7 cells, there was insufficient evidence of autophagy. In a recent study, betavulgarin, isolated from beetroot was found to suppress the growth, migration, colony formation, and mammosphere formation in breast cancer cell lines. This compound also reduced the proportion of

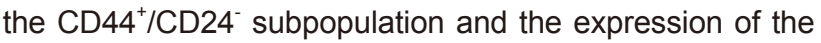
self-renewal-related genes such as c-Myc, Nanog and Oct4. 
Interestingly, betavulgarin inhibited the Stat3/Sox2 signaling and induced breast cancer stem cell death [71].

Oral consumption of red beetroot food color, in the form of commercial dye E162, inhibited N-nitrosomethylbenzylamine (NMBA)-induced tumor formation in the rat esophagus. The number of NMBA-induced esophageal papillomas were significantly reduced by almost half in animals receiving the food color as compared with controls [72]. In addition, the levels of inflammation and angiogenesis in the beetroot-treated animals were also reduced with a concurrent increase in the apoptotic rate. The mechanisms of chemoprevention with red beetroot appeared to involve reduction of cell proliferation, angiogenesis, inflammation and stimulation of apoptosis. Since red beetroot color contains betanins, these effects may be mediated through inhibition of oxygen radical-induced signal transduction [72].

In another study, oral administration of betanin in Institute of Cancer Research (ICR) mice inhibited PMA-induced promotion of mouse skin tumors and glycerol-induced promotion of lung tumors as compared with control [73]. Betanin, in the form of beetroot extract, also significantly decreased tumor multiplicity and burden in two mouse lung tumor models [74]. Subsequent immunohistochemical characterization revealed that betanin reduced angiogenesis and induced apoptosis in treated mice as well as in human cancer cells in vitro [74].

Apart from fresh beetroot juice, beetroot juice fermented with Lactobacillus paracasei 0920 and Lactobacillus brevis 0944 significantly reduced the number of carcinogen-induced aberrant crypt foci in N-nitroso-N-methylurea-treated rats. Hence, supplementation of diet with lacto-fermented beetroot juice was postulated to provide protection against precancerous aberrant crypt formation [75]. In a separate animal study, beetroot minimized radiation-induced DNA damage of splenocytes. Beetroot extract given orally three times to C57BL/6 mice and, at day 10 after $\gamma$-ray irradiation, boosted differentiation of hematopoietic stem cells (HSCs) into burst-forming units-erythroid [76]. Furthermore, beetroot-treated mice also displayed increased levels of red blood cells, hematocrit and hemoglobin. Beetroot supplementation stimulated differentiation of HSCs and preserved integrity of bone marrow [76].

Clinical experiences on beetroot extracts or juice in cancer are currently lacking to support the findings of both in vitro and animal studies. Only an isolated case report on an elderly patient diagnosed with chronic lymphocytic leukemia and her clinical experiences with beetroot juice was published. The patient who refused chlorambucil after a recurrence of disease, was started with beetroot-carrot juice [77]. In the clinical follow-up duration, administration of beetroot-carrot juice alone induced a reduction in lymphocyte and peripheral blood leukocytes count by $14.7 \%$ and $43.13 \%$, respectively with a concurrent decrease in the uric acid level. Administration of beetroot-carrot juice for 15 days resulted in an improved appetite, a sense of general well-being and increased vigor. However, upon discontinuation of the beetroot-carrot juice for 1 month, the patient experienced an increase in cell counts and up-regulation of the uric acid level. Interestingly, her condition was reversed when beetroot-carrot juice was reintroduced. This observation provides single but limited evidence for the effectiveness of the beetroot-carrot juice in eliminating malignant leukemic cells [77].

Polyphenol-rich foods are generally known to have anti-neoplastic effects. A clinical trial demonstrated significant short-term reduction of the prostate-specific antigen (PSA) level following supplementation with polyphenol-rich diet among elderly men [78]. Reduction in the serum PSA level is an endpoint biomarker for hormone-refractory human prostate cancer intervention. Since beetroot contains significant polyphenolic flavonoid antioxidants, its ability to inhibit manifestation of biomarkers of cancer is expected. However, there is certainly limited information on the direct effects of beetroot and its chemical composition on tumour markers i.e., cancer antigen (CA) 125, 15-3, 19-9 and carcinoembryonic antigen (CEA). Prospective clinical studies using beetroot may provide better insight into its underlying mechanisms when given along with standard therapies. A summary of cancer prevention effects of beetroot is shown in Table 2 .

\section{Cardioprotective activities}

Dietary supplementation of beetroot juice has been shown to mitigate anthracycline-induced cardiotoxicity [79]. Doxorubicin and epirubicin are anthracyclines and are usually part of breast cancer treatment protocol. Anthracyclines are important chemotherapeutic agents but unfortunately, chronic administration of anthracyclines induces cardiomyopathy and congestive heart failure [80]. For example, doxorubicin, a quinone-containing anthracycline antibiotic, is widely used to treat solid tumors such as breast and ovarian cancer. However, its clinical use is hampered by its adverse reaction such as cardiomyopathy and congestive heart failure. Although epirubicin or idarubicin, as second-generation analogs, may show improvements in their therapeutic index, there is still risk of cardiomyopathy [80]. One of the commonly known mechanisms of doxorubicin-induced cardiotoxicity is generation of ROS, which induces the apoptosis of the cardiomyocytes [80]. Thus, doxorubicin elicits the formation of hydrogen peroxide and superoxide anions $\left(\mathrm{O}_{2}^{-}\right)$through redox cycling of their aglycones which explains its anti-tumor activities [81].

Inflammation provoked due to ROS generation and oxidative stress is a major adverse effect, especially on the heart $[82,83]$. Hence, improving the antioxidant defences of cardiomyocytes is an important strategy to protect against doxorubicin-induced oxidative death [84]. In an animal study to determine the protective effect of beetroot juice against doxorubicin-induced cardiotoxicity, the combination of beetroot juice with doxorubicin significantly reduced doxorubicin toxicity in rat cardiomyocytes by reducing generation of ROS [84]. Therefore, beetroot juice supplement is postulated to be cardioprotective in patients treated with anthracycline chemo- 


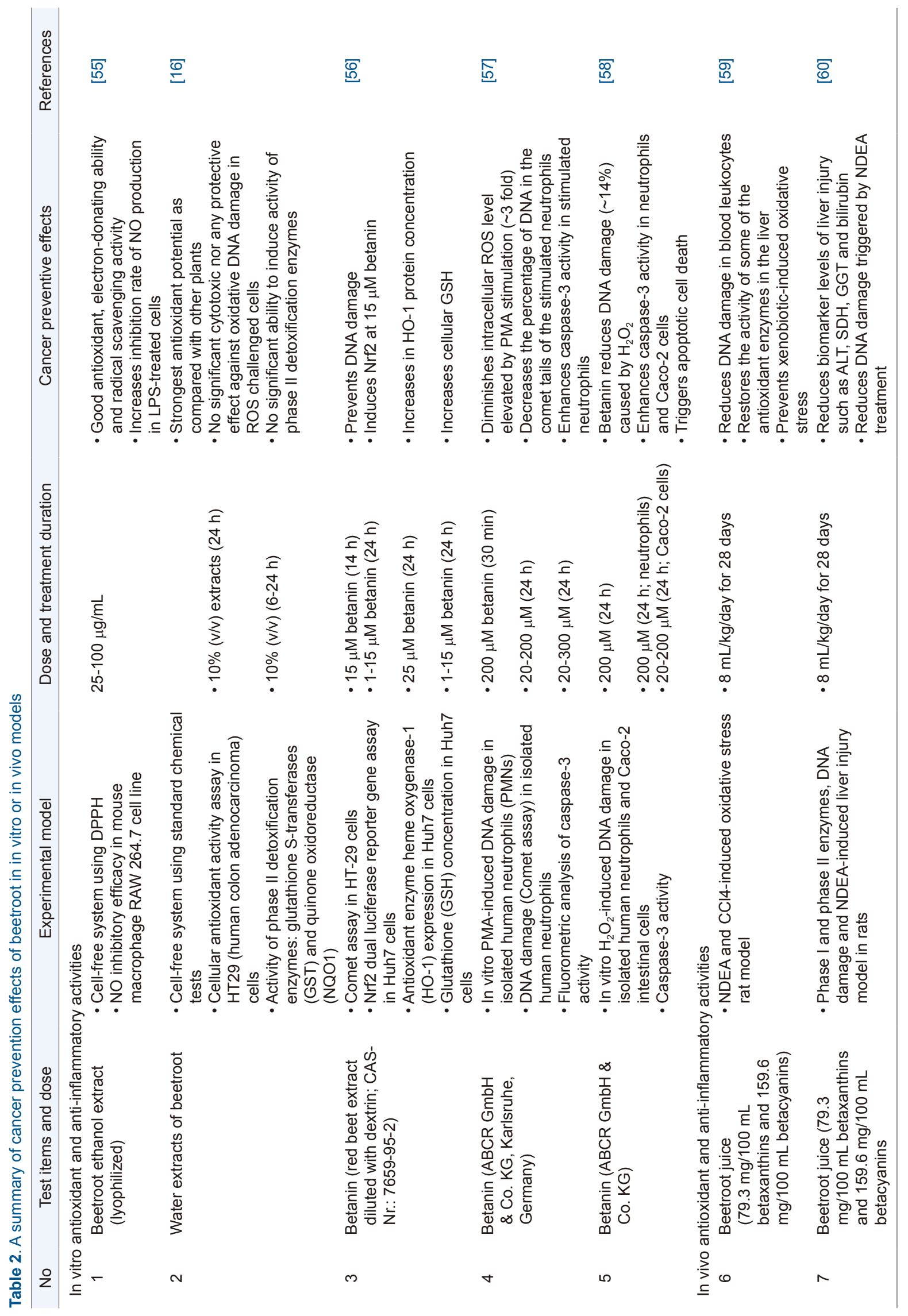




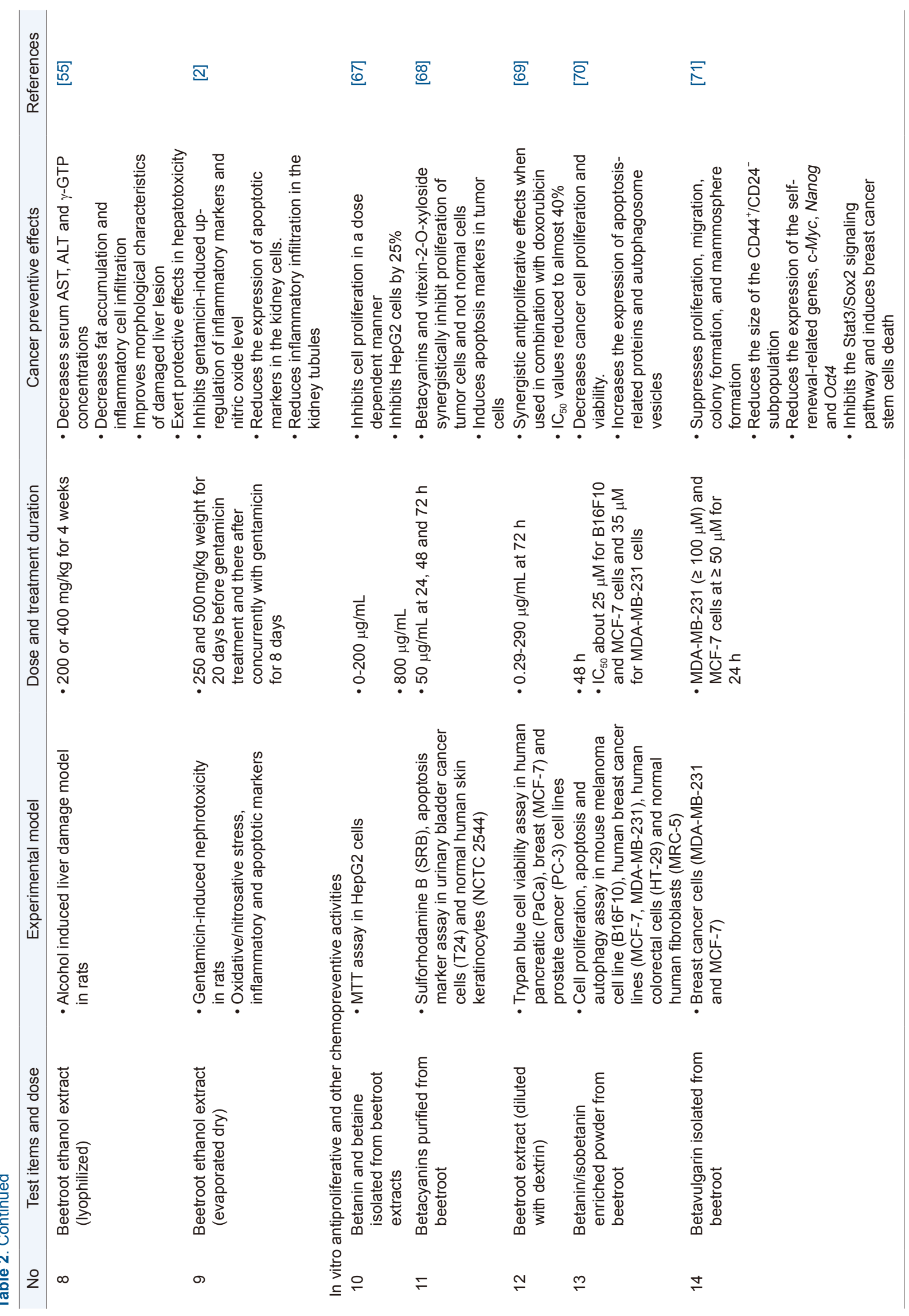




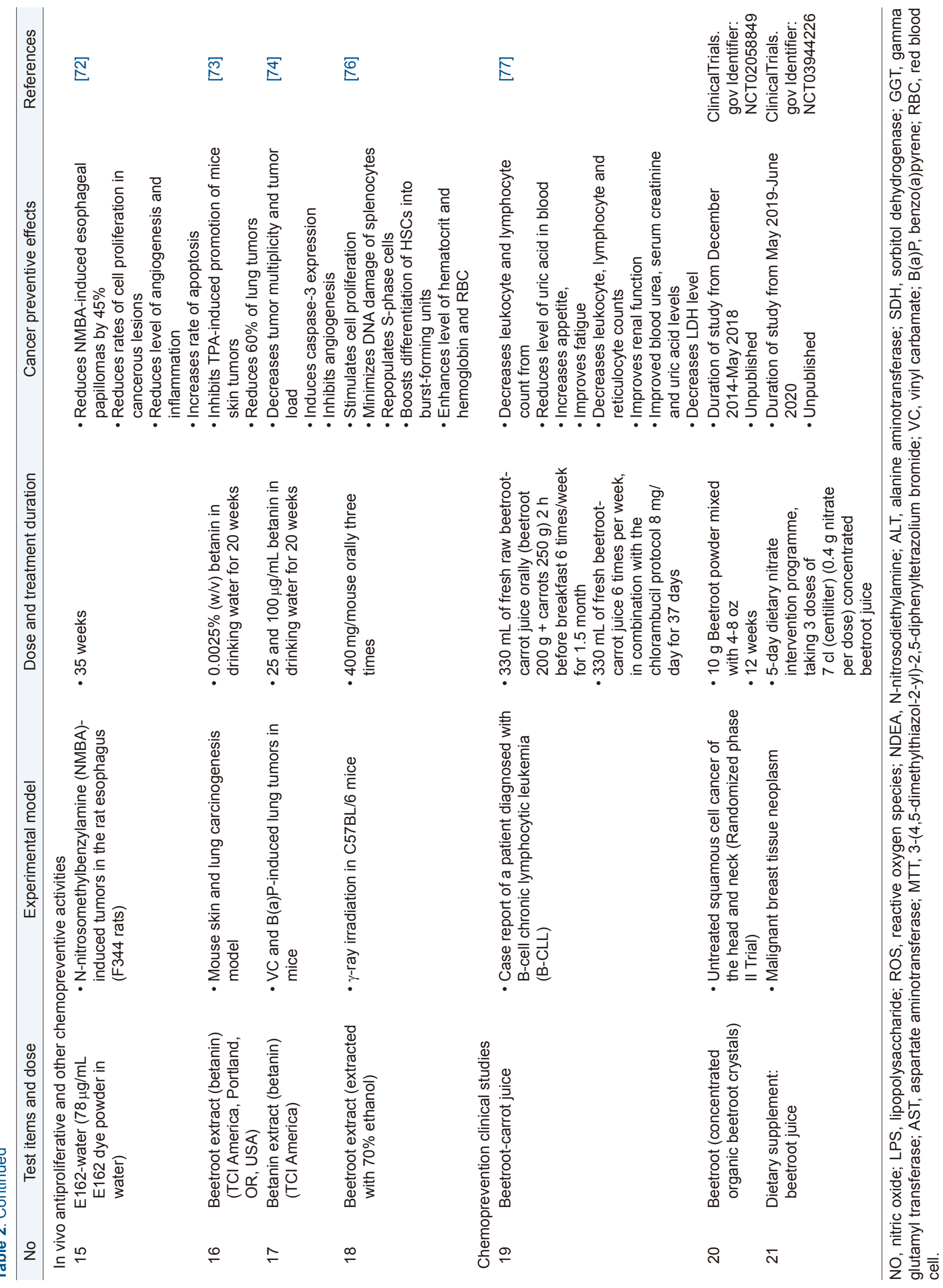


therapeutic drugs. The clinical application of beetroot juice as an adjunct therapy to combat against cardiotoxicity caused by anthracycline drugs is promising and would have a beneficial public health impact [79].

\section{Ameliorating cancer-related fatigue}

Fatigue is a common adverse condition which affects the quality of life of patients with cancer [85]. It is one of the most frequently reported complaints among cancer patients $[86,87]$. As high as $60 \%$ to $93 \%$ of patients undergoing radiotherapy and $80 \%$ to $96 \%$ of patients on chemotherapy experienced fatigue $[87,88]$. Fatigue is reported as one of the most distressing symptoms associated with cancer and its treatment [89]. It is an independent predictor of poor quality of life and patient satisfaction [90]. In addition, the degree of anemia was also found to be predictive of the degree of fatigue among patients with cancer [91].

Off-treatment fatigue, weakness, and less vitality were more prevalent among women who had breast cancer as compared with women who had benign breast problems [92]. In an epidemiology study, breast cancer survivors were found to be complaining of lethargy more frequently than the reference group. A significant number of the breast cancer survivors experienced sleep disturbances, pain and depression which were associated with severe fatigue [93]. In one meta-analysis, one in four breast cancer survivors suffered from severe fatigue. Some of the risk factors included chemotherapy, higher disease stages and combination cancer therapy [94]. In one longitudinal study, persistent fatigue continued to be a challenge for breast carcinoma survivors [95].

The pathogenesis of cancer-related fatigue is currently not well understood. However, its development may be caused by a variety of mechanisms [96]. Cancer-related fatigue could be related to the effects of cancer or its treatment on sleep or circadian rhythms, muscle energy metabolism and central nervous system [97]. Findings from animal and human research suggest that several cancer-related symptoms, notably fatigue and stress, may involved the actions of proinflammatory cytokines [98]. In addition, there were studies which showed links between fatigue and inflammatory markers. Fatigued cancer survivors are characterized by an increased level of TNF- $\alpha$, monocyte production of IL-6, elevated plasma IL-1 receptor antagonist and soluble IL-6 receptor (sIL-6R/ CD126) levels, etc., indicative of immune activation $[99,100]$. Furthermore, the pathogenesis of fatigue is also thought to be related to hormonal changes such as deprivation of androgen or premature menopause in women [101-103]. The usual approaches to treatment of cancer-related fatigue include either pharmacologic management or non-pharmacologic intervention such as patient education. Interestingly, in a systematic review of 77 randomized controlled trials involving non-pharmacologic treatments of cancer-related fatigue, results were promising for non-pharmacologic intervention [104]. These include psychoeducation, hypnosis, exercise, relaxation and cognitive-behavioral interventions.

Functional foods have been increasingly accepted as part of a healthy lifestyle and foods. A nitrate-dietary supplementation with beetroot juice is postulated as a nutritional strategy in patients undergoing chemotherapy and post-chemotherapy due its antioxidant and chemopreventive activities. Symptoms of fatigue may be ameliorated with beetroot supplementation due its high content of dietary nitrates and subsequent production of NO. NO is a ubiquitous signalling molecule with important physiological functions in human tissues [105].

NO plays a crucial role in skeletal muscle metabolic and vascular control. Beetroot juice contains high levels of inorganic nitrate $\left(\mathrm{NO}_{3}{ }^{-}\right)$, which serves as a precursor of $\mathrm{NO}$. Beetroot supplementation provides dietary inorganic nitrate $\left(\mathrm{NO}_{3}{ }^{-}\right)$which positively affect muscle metabolic and haemodynamic function $[106,107]$. Oral $\mathrm{NO}_{3}{ }^{-}$intake, either as beetroot juice or pure sodium $\mathrm{NO}_{3}{ }^{-}$, are found to enhance endurance exercise performance and capacity in young healthy volunteers [107-112]. In humans, acute (2 to 3 hours) and chronic ( 3 to 6 days) dietary nitrate consumption has been shown to improve exercise tolerance and reduce blood pressure $[112,113]$. In addition, beetroot supplementation ameliorates the muscle metabolic perturbations that occur during exercise, improves muscle oxygenation and elevates human mitochondrial efficiency [113-115]. In healthy elderly subjects, serum nitrate concentrations were found to be inversely associated with general fatigue scores based on a self-rating scale (Multidimensional Fatigue Inventory) [116,117]. Similarly, in another study, the level of the job strain appeared to be directly proportional to the fatigue among women but inversely associated with NO levels. NO has the capability to buffer the association between fatigue and job strain [118]. Hence, based on these observations, beetroot juice supplementation and its ability to increase exercise performance and tolerance in healthy subjects may ameliorate cancer-related fatigue. Currently, there are yet any studies to provide direct evidence supporting beetroot's effects on combating fatigue among patients with cancer.

\section{CONCLUSION AND FUTURE PERSPECTIVES}

Beetroot is a vegetable rich in micro-nutrients and bioactive constituents with health beneficial properties and has been gaining attention as a health promoting functional food. The multiple bioactive constituents include the water-soluble betalains consisting of betacyanins and betaxanthins, polyphenols, flavonoids and saponins. Beetroot extracts and betacyanins have been extensively studied both in vitro and in vivo. A variety of studies have demonstrated that beetroot extracts and betanin pigments were effective in preventing experimentally induced carcinogenesis. On the other hand, the flavonoids and polyphenolic components present in abundance in beetroot support its significant anti-inflammatory 
and antioxidant capacities. Although most in vitro and in vivo studies have shown promising results, the molecular mechanisms of betanin chemoprevention have not been completely elucidated and clinical studies on beetroot and cancer are still lacking. In addition, the different extract preparation methods and the lack of pharmacokinetic studies with betanin alone make it difficult to determine if the therapeutic concentration or dosage used in these studies are indeed achievable in human plasma concentration.

In fact, despite containing the richest amount of anti-oxidant compounds, the red beet extract showed neither stronger cytotoxic effect towards HT29 human colon cancer cells, nor the ability to up-regulate the enzymes involved in detoxification as compared with other vegetable or herbal extracts [16]. Although beetroot supplementation has been studied in humans, most clinical studies were performed on a limited sample size and focussed on exercise performance and endurance in healthy cohorts. Two relevant clinical trials involving beetroot and cancer are listed in the ClinicalTrials. gov (US National Library of Medicine) database, which have yet to be published. So far, there has been no clinical study which specifically examines the association between beetroot supplementation and chemo-prevention or cancer-related symptoms such as fatigue, quality of life and well-being or prognosis of disease. Evidence supporting the use of beetroot in managing fatigue and/or managing the harsh side effects of chemotherapy is inevitable for its clinical application. Both epidemiological and randomized clinical studies on beetroot supplementation and patient with cancer are certainly warranted.

Although beetroot, especially nitrates and the betalains, are well absorbed and has good bioavailability in humans, there are still insufficient data on its efficacy and long term safety of beetroot supplementation to propose the food as a longterm strategy in managing diseases like cancer. In pregnancy, nitrate-rich dietary supplementation may be problematic as it may cause a wide range of unexpected maternal and fatal adverse reactions such as thyroid problems, alteration in embryonic cells, methemoglobinemia and other disorders [119]. Hence, intake of excessive beetroot during pregnancy may pose a health hazard. Although beetroot intake provokes no immediate negative health consequences, long term supplementation of beetroot juice should be cautioned in patients with metabolic syndromes or diabetes due to its high sucrose content. In addition, due to beetroot's rich oxalate content, this vegetable can be harmful if taken in large quantities, particularly for individuals at risk of calcium oxalate stone formation in the kidneys [42]. The excretion of red or pink urine after intake of beetroot occurs in $10 \%$ to $14 \%$ of the population. This symptom appeared to be more common in malabsorption and iron deficiency cases [120]. Furthermore, the composition of volatile compounds such as pyridines and 4-methyl-pyridines in beetroot would also warrant further studies with regards to their toxicological properties

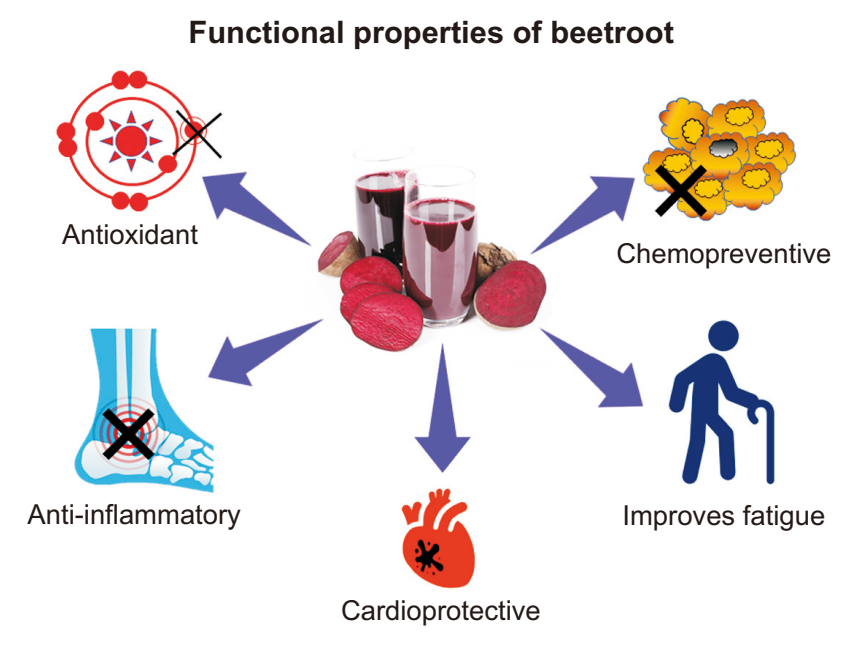

Figure 3. Functional properties of beetroot.

[32]. In addition, their possible interactions with anticancer drugs should also be considered, since a recent case report described a woman who developed methotrexate intoxication after drinking beetroot juice as a herbal remedy [121].

In summary, beetroot is a valuable vegetable to be consumed for health maintenance and has great potential to be used for chemoprevention and in patients with cancer to manage fatigue and other side effects of chemotherapy (Fig. 3). However, long term safety assessment of dietary beetroot supplementation and relevant translational studies are necessary for the clinical setting.

\section{ACKNOWLEDGMENTS}

The authors would like to acknowledge the Smartfund Challenge Grant (MOSTI) and FRGS Grant (KPT).

\section{CONFLICTS OF INTEREST}

No potential conflicts of interest were disclosed.

\section{ORCID}

Mei Lan Tan, https://orcid.org/0000-0001-6565-699X

Shahrul Bariyah Sahul Hamid, https://orcid.org/0000-0002-2843-026X

\section{REFERENCES}

1. Acree TE, Lee CY, Butts RM, Barnard J. Geosmin, the earthy component of table beet odor. J Agric Food Chem 1976;24:4301.

2. El Gamal AA, AISaid MS, Raish M, Al-Sohaibani M, AlMassarani SM, Ahmad A, et al. Beetroot (Beta vulgaris L.) extract ameliorates gentamicin-induced nephrotoxicity associated oxidative stress, inflammation, and apoptosis in 
rodent model. Mediators Inflamm 2014;2014:983952.

3. Jones T, Dunn EL, Macdonald JH, Kubis HP, McMahon N, Sandoo A. The effects of beetroot juice on blood pressure, microvascular function and large-vessel endothelial function: a randomized, double-blind, placebo-controlled pilot study in healthy older adults. Nutrients 2019;11:1792.

4. Siervo M, Shannon O, Kandhari N, Prabhakar M, Fostier W, Köchl C, et al. Nitrate-rich beetroot juice reduces blood pressure in Tanzanian adults with elevated blood pressure: a double-blind randomized controlled feasibility trial. J Nutr 2020;150:2460-8.

5. Stanaway L, Rutherfurd-Markwick K, Page R, Wong M, Jirangrat $\mathrm{W}$, Teh $\mathrm{KH}$, et al. Acute supplementation with nitraterich beetroot juice causes a greater increase in plasma nitrite and reduction in blood pressure of older compared to younger adults. Nutrients 2019;11:1683.

6. Morris RC Jr, Pravenec M, Šilhavý J, DiCarlo SE, Kurtz TW. Small amounts of inorganic nitrate or beetroot provide substantial protection from salt-induced increases in blood pressure. Hypertension 2019;73:1042-8.

7. Ormsbee MJ, Bach CW, Baur DA. Pre-exercise nutrition: the role of macronutrients, modified starches and supplements on metabolism and endurance performance. Nutrients 2014;6:1782-808.

8. McQuillan JA, Casadio JR, Dulson DK, Laursen PB, Kilding AE. The effect of nitrate supplementation on cycling performance in the heat in well-trained cyclists. Int J Sports Physiol Perform 2018;13:50-6.

9. Nyakayiru J, Jonvik KL, Trommelen J, Pinckaers PJ, Senden $\mathrm{JM}$, van Loon LJ, et al. Beetroot juice supplementation improves high-intensity intermittent type exercise performance in trained soccer players. Nutrients 2017;9:314.

10. Montenegro CF, Kwong DA, Minow ZA, Davis BA, Lozada CF, Casazza GA. Betalain-rich concentrate supplementation improves exercise performance and recovery in competitive triathletes. Appl Physiol Nutr Metab 2017;42:166-72.

11. Javadi B. Diet therapy for cancer prevention and treatment based on Traditional Persian Medicine. Nutr Cancer 2018;70:376-403.

12. Clement $Y N$, Mahase V, Jagroop A, Kissoon K, Maharaj A, Mathura $P$, et al. Herbal remedies and functional foods used by cancer patients attending specialty oncology clinics in Trinidad. BMC Complement Altern Med 2016;16:399.

13. Obrist R, von Meiss M, Obrecht JP. [The use of paramedical treatment methods by cancer patients. A inquiry on 101 ambulatory patients]. Dtsch Med Wochenschr 1986;111:283-7. German

14. Nikolić I, Smiljenić D, Kukić B, Bogdanović B, Petrović T, Ivković-Kapicl T, et al. Application of alternative medicine in gastrointestinal cancer patients. Vojnosanit Pregl 2012;69:94750.

15. Tesoriere L, Allegra M, Butera D, Livrea MA. Absorption, excretion, and distribution of dietary antioxidant betalains in LDLs: potential health effects of betalains in humans. Am J Clin Nutr 2004;80:941-5.
16. Koss-Mikołajczyk I, Kusznierewicz B, Wiczkowski W, Sawicki $\mathrm{T}$, Bartoszek A. The comparison of betalain composition and chosen biological activities for differently pigmented prickly pear (Opuntia ficus-indica) and beetroot (Beta vulgaris) varieties. Int J Food Sci Nutr 2019;70:442-52.

17. Gandía-Herrero F, García-Carmona F, Escribano J. Fluorescent pigments: new perspectives in betalain research and applications. Food Res Int 2005;38:879-84.

18. Kanner J, Harel S, Granit R. Betalains--a new class of dietary cationized antioxidants. J Agric Food Chem 2001;49:5178-85.

19. Strack D, Vogt T, Schliemann W. Recent advances in betalain research. Phytochemistry 2003;62:247-69.

20. Kujala T, Loponen J, Pihlaja K. Betalains and phenolics in red beetroot (Beta vulgaris) peel extracts: extraction and characterisation. Z Naturforsch C J Biosci 2001;56:343-8.

21. Alard D, Wray V, Grotjahn L, Reznik H, Strack D. Neobetanin: isolation and identification from Beta vulgaris. Phytochemistry 1985;24:2383-85.

22. Bokern M, Heuer S, Wray V, Witte L, Macek T, Vanek T, et al. Ferulic acid conjugates and betacyanins from cell cultures of Beta vulgaris. Phytochemistry 1991;30:3261-5.

23. Pourrat A, Lejeune B, Grand A, Pourrat $H$. Betalains assay of fermented red beet root extract by high performance liquid chromatography. J Food Sci 1988;53:294-5.

24. Chhikara N, Kushwaha K, Sharma P, Gat Y, Panghal A. Bioactive compounds of beetroot and utilization in food processing industry: a critical review. Food Chem 2019;272:192200.

25. Georgiev VG, Weber J, Kneschke EM, Denev PN, Bley T, Pavlov Al. Antioxidant activity and phenolic content of betalain extracts from intact plants and hairy root cultures of the red beetroot Beta vulgaris cv. Detroit dark red. Plant Foods Hum Nutr 2010;65:105-11.

26. Maraie NK, Abdul-Jalil TZ, Alhamdany AT, Janabi HA. Phytochemical study of the Iraqi Beta vulgaris leaves and its clinical applications for the treatment of different dermatological diseases. World J Pharm Pharm Sci 2014;3:5-19.

27. Nemzer B, Pietrzkowski Z, Spórna A, Stalica P, Thresher $\mathrm{W}$, Michałowski T, et al. Betalainic and nutritional profiles of pigment-enriched red beet root (Beta vulgaris L.) dried extracts. Food Chem 2011;127:42-53.

28. Kujala TS, Vienola MS, Klika KD, Loponen JM, Pihlaja K. Betalain and phenolic compositions of four beetroot (Beta vulgaris) cultivars. Eur Food Res Technol 2002;214:505-10.

29. Lim TK. Beta vulgaris. In: Lim TK, ed. Edible Medicinal and Non-Medicinal Plants. Volume 10. Dordrecht, Springer, pp 2668, 2016.

30. Kujala T, Klika K, Ovcharenko V, Loponen J, Vienola M, Pihlaja K. 5,5',6,6'-Tetrahydroxy-3,3'-biindolyl from beetroot (Beta vulgaris) peel extract. Z Naturforsch C J Biosci 2001;56:714-8.

31. Kujala TS, Loponen JM, Klika KD, Pihlaja K. Phenolics and betacyanins in red beetroot (Beta vulgaris) root: distribution and effect of cold storage on the content of total phenolics and three individual compounds. J Agric Food Chem 2000;48:5338-42. 
32. Parliment TH, Kolor MG, Maing IY. Identification of the major volatile components of cooked beets. J Food Sci 1977;42:15923.

33. Pasch JH, von Elbe JH. Sensory evaluation of betanine and concentrated beet juice. J Food Sci 1978;43:1624-5.

34. Sobhy ES, Abdo E, Shaltout O, Abdalla A, Zeitoun A. Nutritional evaluation of beetroots (Beta vulgaris L.) and its potential application in a functional beverage. Plants (Basel) 2020;9:1752.

35. Westall RG. The use of ion-exchange resins for the isolation of glutamine and other nitrogenous substances from beetroot. J Sci Food Agric 1950;1:191-3.

36. Wang AL, Niu Q, Shi N, Wang J, Jia XF, Lian HF, et al. Glutamine ameliorates intestinal ischemia-reperfusion injury in rats by activating the Nrf2/Are signaling pathway. Int J Clin Exp Pathol 2015;8:7896-904.

37. Alves WF, Aguiar EE, Guimarães SB, da Silva Filho AR, Pinheiro PM, Soares Gdos S, et al. L-alanyl-glutamine preoperative infusion in patients with critical limb ischemia subjected to distal revascularization reduces tissue damage and protects from oxidative stress. Ann Vasc Surg 2010;24:461-7.

38. Newsholme P, Lima MM, Procopio J, Pithon-Curi TC, Doi SQ, Bazotte RB, et al. Glutamine and glutamate as vital metabolites. Braz J Med Biol Res 2003;36:153-63.

39. Westall RG. Isolation of gamma-Amino-butyric acid from beetroot (beta vulgaris. Nature 1950;165:717.

40. Cho YR, Chang JY, Chang HC. Production of gammaaminobutyric acid (GABA) by Lactobacillus buchneri isolated from kimchi and its neuroprotective effect on neuronal cells. J Microbiol Biotechnol 2007; 17:104-9.

41. Inoue K, Shirai T, Ochiai H, Kasao M, Hayakawa K, Kimura $M$, et al. Blood-pressure-lowering effect of a novel fermented milk containing gamma-aminobutyric acid (GABA) in mild hypertensives. Eur J Clin Nutr 2003;57:490-5.

42. Santamaria P, Elia A, Serio F, Todaro E. A survey of nitrate and oxalate content in fresh vegetables. J Sci Food Agric 1999;79:1882-8.

43. Kapil V, Milsom AB, Okorie M, Maleki-Toyserkani S, Akram F, Rehman F, et al. Inorganic nitrate supplementation lowers blood pressure in humans: role for nitrite-derived NO. Hypertension 2010;56:274-81.

44. Moncada S, Higgs EA. Nitric oxide and the vascular endothelium. Handb Exp Pharmacol 2006;(176 Pt 1):213-54.

45. Ahluwalia A, Gladwin M, Coleman GD, Hord N, Howard G, Kim-Shapiro DB, et al. Dietary nitrate and the epidemiology of cardiovascular disease: report from a National Heart, Lung, and Blood Institute workshop. J Am Heart Assoc 2016;5:e003402.

46. Mills CE, Khatri J, Maskell P, Odongerel C, Webb AJ. It is rocket science - why dietary nitrate is hard to 'beet'! Part II: further mechanisms and therapeutic potential of the nitrate-nitrite-NO pathway. Br J Clin Pharmacol 2017;83:140-51.

47. Song W, Derito CM, Liu MK, He X, Dong M, Liu RH. Cellular antioxidant activity of common vegetables. J Agric Food Chem 2010;58:6621-9.

48. Pedreño MA, Escribano J. Studying the oxidation and the antiradical activity of betalain from beetroot. J Biol Educ 2000;35:49-51.

49. Pavlov A, Kovatcheva P, Georgiev V, Koleva I, Ilieva M. Biosynthesis and radical scavenging activity of betalains during the cultivation of red beet (Beta vulgaris) hairy root cultures. Z Naturforsch C J Biosci 2002;57:640-4.

50. Kayashima T, Katayama T. Oxalic acid is available as a natural antioxidant in some systems. Biochim Biophys Acta 2002;1573:1-3.

51. Wettasinghe M, Bolling B, Plhak L, Xiao H, Parkin K. Phase II enzyme-inducing and antioxidant activities of beetroot (Beta vulgaris L.) extracts from phenotypes of different pigmentation. J Agric Food Chem 2002;50:6704-9.

52. Mohdaly AA, Sarhan MA, Smetanska I, Mahmoud A. Antioxidant properties of various solvent extracts of potato peel, sugar beet pulp and sesame cake. J Sci Food Agric 2010;90:218-26.

53. Rehman S, Shah S, Mehmood Butt A, Masood Shah S, Jabeen $Z$, Nadeem A. Biochemical profiling and elucidation of biological activities of Beta vulgaris L. leaves and roots extracts. Saudi J Biol Sci 2021;28:592-602.

54. Hajihosseini S, Setorki M, Hooshmandi Z. The antioxidant activity of Beta vulgaris leaf extract in improving scopolamineinduced spatial memory disorders in rats. Avicenna J Phytomed 2017;7:417-25.

55. Kim BH, Jung SH, Jung S. Beet root (Beta vulgaris) protects lipopolysaccharide and alcohol-induced liver damage in rat. Toxicol Res 2020;36:275-82.

56. Esatbeyoglu T, Wagner AE, Motafakkerazad R, Nakajima Y, Matsugo S, Rimbach G. Free radical scavenging and antioxidant activity of betanin: electron spin resonance spectroscopy studies and studies in cultured cells. Food Chem Toxicol 2014;73:119-26.

57. Zielińska-Przyjemska M, Olejnik A, Kostrzewa A, Łuczak M, Jagodziński PP, Baer-Dubowska W. The beetroot component betanin modulates ROS production, DNA damage and apoptosis in human polymorphonuclear neutrophils. Phytother Res 2012;26:845-52.

58. Zielińska-Przyjemska M, Olejnik A, Dobrowolska-Zachwieja A, Łuczak M, Baer-Dubowska W. DNA damage and apoptosis in blood neutrophils of inflammatory bowel disease patients and in Caco-2 cells in vitro exposed to betanin. Postepy Hig Med Dosw (Online) 2016;70:265-71.

59. Kujawska M, Ignatowicz E, Murias M, Ewertowska M, Mikołajczyk K, Jodynis-Liebert J. Protective effect of red beetroot against carbon tetrachloride- and $\mathrm{N}$-nitrosodiethylamine-induced oxidative stress in rats. J Agric Food Chem 2009;57:2570-5.

60. Krajka-Kuźniak V, Szaefer H, Ignatowicz E, Adamska T, Baer-Dubowska W. Beetroot juice protects against $\mathrm{N}$-nitrosodiethylamine-induced liver injury in rats. Food Chem Toxicol 2012;50:2027-33.

61. Baker RG, Hayden MS, Ghosh S. NF-кB, inflammation, and metabolic disease. Cell Metab 2011;13:11-22.

62. Zielińska-Przyjemska M, Olejnik A, Dobrowolska-Zachwieja A, Grajek W. In vitro effects of beetroot juice and chips on oxidative 
metabolism and apoptosis in neutrophils from obese individuals. Phytother Res 2009;23:49-55.

63. Vidal PJ, López-Nicolás JM, Gandía-Herrero F, GarcíaCarmona F. Inactivation of lipoxygenase and cyclooxygenase by natural betalains and semi-synthetic analogues. Food Chem 2014;154:246-54.

64. Reddy MK, Alexander-Lindo RL, Nair MG. Relative inhibition of lipid peroxidation, cyclooxygenase enzymes, and human tumor cell proliferation by natural food colors. J Agric Food Chem 2005;53:9268-73.

65. Clifford T, Howatson G, West DJ, Stevenson EJ. The potential benefits of red beetroot supplementation in health and disease. Nutrients 2015;7:2801-22.

66. Sreekanth D, Arunasree MK, Roy KR, Chandramohan Reddy T, Reddy GV, Reddanna P. Betanin a betacyanin pigment purified from fruits of Opuntia ficus-indica induces apoptosis in human chronic myeloid leukemia Cell line-K562. Phytomedicine 2007;14:739-46.

67. Lee EJ, An D, Nguyen CT, Patil BS, Kim J, Yoo KS. Betalain and betaine composition of greenhouse- or field-produced beetroot (Beta vulgaris L.) and inhibition of HepG2 cell proliferation. J Agric Food Chem 2014;62:1324-31.

68. Scarpa ES, Emanuelli M, Frati A, Pozzi V, Antonini E, Diamantini $\mathrm{G}$, et al. etacyanins enhance vitexin-2-O-xyloside mediated inhibition of proliferation of T24 bladder cancer cells. Food Funct 2016;7:4772-80

69. Kapadia GJ, Rao GS, Ramachandran C, lida A, Suzuki N, Tokuda H. Synergistic cytotoxicity of red beetroot (Beta vulgaris L.) extract with doxorubicin in human pancreatic, breast and prostate cancer cell lines. J Complement Integr Med 2013;10:113-22.

70. Nowacki L, Vigneron P, Rotellini L, Cazzola H, Merlier F, Prost $\mathrm{E}$, et al. Betanin-enriched red beetroot (Beta vulgaris L.) extract induces apoptosis and autophagic cell death in MCF-7 cells. Phytother Res 2015;29:1964-73.

71. Liu R, Choi HS, Zhen X, Kim SL, Kim JH, Ko YC, et al. Betavulgarin isolated from sugar beet (Beta vulgaris) suppresses breast cancer stem cells through Stat3 signaling. Molecules 2020;25:2999.

72. Lechner JF, Wang LS, Rocha CM, Larue B, Henry C, Mclntyre $\mathrm{CM}$, et al. Drinking water with red beetroot food color antagonizes esophageal carcinogenesis in $\mathrm{N}$-nitrosomethylbenzylamine-treated rats. J Med Food 2010;13:733-9.

73. Kapadia GJ, Tokuda H, Konoshima T, Nishino H. Chemoprevention of lung and skin cancer by Beta vulgaris (beet) root extract. Cancer Lett 1996;100:211-4.

74. Zhang Q, Pan J, Wang Y, Lubet R, You M. Beetroot red (betanin) inhibits vinyl carbamate- and benzo(a)pyreneinduced lung tumorigenesis through apoptosis. Mol Carcinog 2013;52:686-91.

75. Klewicka E, Nowak A, Zduńczyk Z, Cukrowska B, Błasiak J. Protective effect of lactofermented beetroot juice against aberrant crypt foci formation and genotoxicity of fecal water in rats. Exp Toxicol Pathol 2012;64:599-604

76. Cho J, Bing SJ, Kim A, Lee NH, Byeon SH, Kim GO, et al. Beetroot (Beta vulgaris) rescues mice from $\gamma$-ray irradiation by accelerating hematopoiesis and curtailing immunosuppression. Pharm Biol 2017;55:306-19.

77. Shakib MC, Gabrial SG, Gabrial GN. Beetroot-carrot juice intake either alone or in combination with antileukemic drug 'chlorambucil' as a potential treatment for chronic lymphocytic leukemia. Open Access Maced J Med Sci 2015;3:331-6.

78. Thomas R, Williams M, Sharma H, Chaudry A, Bellamy P. A double-blind, placebo-controlled randomised trial evaluating the effect of a polyphenol-rich whole food supplement on PSA progression in men with prostate cancer--the U.K. NCRN Pomi-T study. Prostate Cancer Prostatic Dis 2014;17:180-6.

79. Kuriakose RK, Kukreja RC, Xi L. Potential therapeutic strategies for hypertension-exacerbated cardiotoxicity of anticancer drugs. Oxid Med Cell Longev 2016;2016:8139861.

80. Minotti G, Menna P, Salvatorelli E, Cairo G, Gianni L. Anthracyclines: molecular advances and pharmacologic developments in antitumor activity and cardiotoxicity. Pharmacol Rev 2004;56:185-229.

81. Simůnek T, Stérba M, Popelová $\mathrm{O}$, Adamcová M, Hrdina R, GersI V. Anthracycline-induced cardiotoxicity: overview of studies examining the roles of oxidative stress and free cellular iron. Pharmacol Rep 2009;61:154-71.

82. Guo W, Kong E, Meydani M. Dietary polyphenols, inflammation, and cancer. Nutr Cancer 2009;61:807-10.

83. Ziech D, Franco R, Georgakilas AG, Georgakila S, MalamouMitsi $\mathrm{V}$, Schoneveld $\mathrm{O}$, et al. The role of reactive oxygen species and oxidative stress in environmental carcinogenesis and biomarker development. Chem Biol Interact 2010;188:334-9.

84. Das S, Filippone SM, Williams DS, Das A, Kukreja RC. Beet root juice protects against doxorubicin toxicity in cardiomyocytes while enhancing apoptosis in breast cancer cells. Mol Cell Biochem 2016;421:89-101.

85. Gupta D, Lis CG, Grutsch JF. The relationship between cancerrelated fatigue and patient satisfaction with quality of life in cancer. J Pain Symptom Manage 2007;34:40-7.

86. Ahlberg K, Ekman T, Gaston-Johansson F, Mock V. Assessment and management of cancer-related fatigue in adults. Lancet 2003;362:640-50.

87. Stasi R, Abriani L, Beccaglia P, Terzoli E, Amadori S. Cancerrelated fatigue: evolving concepts in evaluation and treatment. Cancer 2003;98:1786-801.

88. Curt GA. The impact of fatigue on patients with cancer: overview of FATIGUE 1 and 2. Oncologist 2000;5 Suppl 2:9-12.

89. Stone P, Richardson A, Ream E, Smith AG, Kerr DJ, Kearney N. Cancer-related fatigue: inevitable, unimportant and untreatable? Results of a multi-centre patient survey. Cancer Fatigue Forum. Ann Oncol 2000;11:971-5.

90. Lis CG, Rodeghier M, Grutsch JF, Gupta D. Distribution and determinants of patient satisfaction in oncology with a focus on health related quality of life. BMC Health Serv Res 2009;9:190.

91. Cella D, Lai JS, Chang CH, Peterman A, Slavin M. Fatigue in 
cancer patients compared with fatigue in the general United States population. Cancer 2002;94:528-38.

92. Andrykowski MA, Curran SL, Lightner R. Off-treatment fatigue in breast cancer survivors: a controlled comparison. J Behav Med 1998;21:1-18.

93. Bower JE, Ganz PA, Desmond KA, Rowland JH, Meyerowitz $\mathrm{BE}$, Belin TR. Fatigue in breast cancer survivors: occurrence, correlates, and impact on quality of life. J Clin Oncol 2000;18:743-53.

94. Abrahams HJG, Gielissen MFM, Schmits IC, Verhagen CAHHVM, Rovers MM, Knoop H. Risk factors, prevalence, and course of severe fatigue after breast cancer treatment: a metaanalysis involving 12327 breast cancer survivors. Ann Oncol 2016;27:965-74.

95. Bower JE, Ganz PA, Desmond KA, Bernaards C, Rowland JH, Meyerowitz BE, et al. Fatigue in long-term breast carcinoma survivors: a longitudinal investigation. Cancer 2006;106:751-8.

96. Gutstein HB. The biologic basis of fatigue. Cancer 2001;92(6 Suppl):1678-83.

97. Parker KP, Bliwise DL, Ribeiro M, Jain SR, Vena CI, KohlesBaker MK, et al. Sleep/Wake patterns of individuals with advanced cancer measured by ambulatory polysomnography. J Clin Oncol 2008;26:2464-72.

98. Cleeland CS, Bennett GJ, Dantzer R, Dougherty PM, Dunn AJ, Meyers CA, et al. Are the symptoms of cancer and cancer treatment due to a shared biologic mechanism? A cytokineimmunologic model of cancer symptoms. Cancer 2003;97:291925.

99. Collado-Hidalgo A, Bower JE, Ganz PA, Cole SW, Irwin MR. Inflammatory biomarkers for persistent fatigue in breast cancer survivors. Clin Cancer Res 2006;12:2759-66.

100. Scott HR, McMillan DC, Forrest LM, Brown DJ, McArdle CS, Milroy R. The systemic inflammatory response, weight loss, performance status and survival in patients with inoperable nonsmall cell lung cancer. Br J Cancer 2002;87:264-7.

101. Fan HG, Houédé-Tchen N, Yi QL, Chemerynsky I, Downie FP, Sabate K, et al. Fatigue, menopausal symptoms, and cognitive function in women after adjuvant chemotherapy for breast cancer: 1- and 2-year follow-up of a prospective controlled study. J Clin Oncol 2005;23:8025-32.

102. Nelson AM, Gonzalez BD, Jim HS, Cessna JM, Sutton SK, Small BJ, et al. Characteristics and predictors of fatigue among men receiving androgen deprivation therapy for prostate cancer: a controlled comparison. Support Care Cancer 2016;24:415966.

103. Campos MPO, Hassan BJ, Riechelmann R, Del Giglio A. Cancer-related fatigue: a practical review. Ann Oncol 2011;22:1273-9.

104. Lotfi-Jam K, Carey M, Jefford M, Schofield P, Charleson C, Aranda S. Nonpharmacologic strategies for managing common chemotherapy adverse effects: a systematic review. J Clin Oncol 2008;26:5618-29.

105. Stamler JS, Meissner G. Physiology of nitric oxide in skeletal muscle. Physiol Rev 2001;81:209-37.
106. Larsen FJ, Weitzberg E, Lundberg JO, Ekblom B. Effects of dietary nitrate on oxygen cost during exercise. Acta Physiol (Oxf) 2007;191:59-66.

107. Bailey SJ, Winyard P, Vanhatalo A, Blackwell JR, Dimenna FJ, Wilkerson DP, et al. Dietary nitrate supplementation reduces the $\mathrm{O} 2$ cost of low-intensity exercise and enhances tolerance to high-intensity exercise in humans. J Appl Physiol (1985) 2009;107:1144-55.

108. Lansley KE, Winyard PG, Bailey SJ, Vanhatalo A, Wilkerson $\mathrm{DP}$, Blackwell JR, et al. Acute dietary nitrate supplementation improves cycling time trial performance. Med Sci Sports Exerc 2011;43:1125-31.

109. Lansley KE, Winyard PG, Fulford J, Vanhatalo A, Bailey SJ, Blackwell JR, et al. Dietary nitrate supplementation reduces the $\mathrm{O} 2$ cost of walking and running: a placebo-controlled study. J Appl Physiol (1985) 2011;110:591-600.

110. Bond H, Morton L, Braakhuis AJ. Dietary nitrate supplementation improves rowing performance in well-trained rowers. Int J Sport Nutr Exerc Metab 2012;22:251-6.

111. Cermak NM, Gibala MJ, van Loon LJ. Nitrate supplementation's improvement of 10-km time-trial performance in trained cyclists. Int J Sport Nutr Exerc Metab 2012;22:64-71.

112. Vanhatalo A, Bailey SJ, Blackwell JR, DiMenna FJ, Pavey TG, Wilkerson DP, et al. Acute and chronic effects of dietary nitrate supplementation on blood pressure and the physiological responses to moderate-intensity and incremental exercise. Am J Physiol Regul Integr Comp Physiol 2010;299:R1121-31.

113. Kenjale AA, Ham KL, Stabler T, Robbins JL, Johnson JL, Vanbruggen $\mathrm{M}$, et al. Dietary nitrate supplementation enhances exercise performance in peripheral arterial disease. J Appl Physiol (1985) 2011;110:1582-91.

114. Vanhatalo A, Fulford J, Bailey SJ, Blackwell JR, Winyard $P G$, Jones AM. Dietary nitrate reduces muscle metabolic perturbation and improves exercise tolerance in hypoxia. $\mathrm{J}$ Physiol 2011;589(Pt 22):5517-28.

115. Larsen FJ, Schiffer TA, Borniquel S, Sahlin K, Ekblom $B$, Lundberg JO, et al. Dietary inorganic nitrate improves mitochondrial efficiency in humans. Cell Metab 2011;13:149-59.

116. Capuron L, Schroecksnadel S, Féart C, Aubert A, Higueret D, Barberger-Gateau $\mathrm{P}$, et al. Chronic low-grade inflammation in elderly persons is associated with altered tryptophan and tyrosine metabolism: role in neuropsychiatric symptoms. Biol Psychiatry 2011;70:175-82.

117. Smets EM, Garssen B, Bonke B, De Haes JC. The Multidimensional Fatigue Inventory (MFI) psychometric qualities of an instrument to assess fatigue. J Psychosom Res 1995;39:31525.

118. Takaki J. Circulating nitrite and nitrate are associated with jobrelated fatigue in women, but not in men. Int $\mathrm{J}$ Environ Res Public Health 2013;10:2813-24.

119. Bahadoran Z, Mirmiran P, Azizi F, Ghasemi A. Nitrate-rich dietary supplementation during pregnancy: the pros and cons. Pregnancy Hypertens 2018;11:44-6.

120. Watts AR, Lennard MS, Mason SL, Tucker GT, Woods 
HF. Beeturia and the biological fate of beetroot pigments. Pharmacogenetics 1993;3:302-11.

121. Gönül M, Keseroglu H, Hacınecipoğlu F. A case of methotrexate intoxication in a patient with psoriasis who drank beetroot juice during methotrexate treatment. Clin Exp Dermatol 2016;41:8935. 